\title{
Studi Eksperimen Karakteristik Mekanik Material Screw Press Kapasitas 10-14 Ton/Jam Di Lingkungan Pabrik Kelapa Sawit
}

\author{
Rinaldi $^{1)}$, Siswo Pranoto ${ }^{2)}$, Rafasiro Afriza ${ }^{3)}$ \\ ${ }^{1), 2)}$ Dosen Jurusan Teknik mesin Sekolah Tinggi Teknologi Pekanbaru \\ ${ }^{3)}$ Mahasiswa Jurusan Teknik Mesin Sekolah Tinggi Teknologi Pekanbaru \\ Jl. Dirgantara No.4 Arengka Pekanbaru-Riau 2829 \\ E-mail : rinaldiyds@gmail.com
}

\begin{abstract}
Abstrak
Sawit merupakan salah satu tanaman penghasil minyak sawit (Cruide Palm Oil) dan inti sawit (Palm Kernel) dan menjadi primadona tanaman perkebunan yang menjadi sumber devisa non migas bagi Indonesia. Salah satu proses terpenting untuk mendapatkan minyak kelapa sawit ada pada mesin screw press. Mesin ini berfungsi memeras buah sawit untuk mendapat minyak sawit. Mesin screw press ini sering terjadi kerusakan yaitu ausnya pisau press pada saat memeras buah sawit, hal ini disebabkan oleh faktor lama pemakaian, perawatan, dan material screw press. Penelitian ini dilakukan untuk mengetahui karakteristik material screw press dengan melakukan beberapa pengujian, menganalisa gaya dan tegangan pada screw press. Pengujian yang dilakukan adalah: uji tarik, uji kekerasan, struktur mikro, dan komposisi kimia. dimana dari hasil pengujian yang dilakukan didapatkan hasil yaitu: tegangan tarik sebesar $78 \mathrm{~kg} / \mathrm{mm}^{2}$, keuletan screw 4,64\%, sementara berdasarkan standar dari material screw press tegangan tarik screw press adalah $100 \mathrm{~kg} / \mathrm{mm}^{2}$. Pengujian kekerasan dari tiga titik pengujian pada salah satu titik kekerasannya berbeda. Sedangkan gaya tekan yang terjadi pada screw adalah sebesar 264

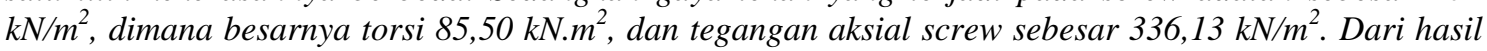
uji yang telah dilakukan dapat disimpulkan besarnya selisih tegangan tarik spesimen uji dengan standar pabrik sangat jauh, serta kekerasan permukaan screw yang tidak sama sangat mempengarui tingkat aus pada material screw press.
\end{abstract}

Kata kunci : screw press, tegangan tarik, kekerasan, struktur mikro, komposisi bahan

\begin{abstract}
Palm is one of the palm oil producing plants (Cruide Palm Oil) and palm kernel (Palm Kernel) and became the prima donna of plantation crops that became a source of non-oil foreign exchange for Indonesia. One of the most important processes for obtaining palm oil is on a screw press machine. This machine serves to squeeze the palm fruit to get palm oil. Screw press machine is often a damage that is wear knife press when squeezing the palm fruit, this is caused by the long-time usage, care, and screw press material. This study was conducted to determine the characteristics of screw press material by performing several tests, analyzing the force and stress on the screw press. Tests performed are: tensile test, hardness test, microstructure, and chemical composition. Where the results of the test results obtained are: tensile stress of $78 \mathrm{~kg} / \mathrm{mm} 2$, screw ductility 4.64\%, while based. on the standard of screw press material tensile pressure screw press is $100 \mathrm{~kg} / \mathrm{mm} 2$. Hardness testing of three test points at one of its different points of violence. While the compressive force that occurs on the screw is $264 \mathrm{KN} / \mathrm{m} 2$, where the magnitude of torque is $85.50 \mathrm{kN.m2}$, and the axial voltage of the screw is $336.13 \mathrm{KN} / \mathrm{m} 2$. From the results of tests that have been done can be concluded that the amount of tensile stresses of test specimens with the factory standard is very far, and the uneven surface hardness of screw deeply affect the wear level on the screw press material.
\end{abstract}

Keywords: screw press, tensile stress, hardness, micro structure, material composition 


\section{Pendahuluan}

Sawit adalah tanaman penghasil minyak sawit (Crude Palm Oil) dan inti sawit (Palm Kernel) merupakan salah satu primadona tanaman perkebunan yang menjadi sumber penghasil devisa non migas bagi Indonesia. Dalam proses pengolahan buah sawit dilakukan dengan menggunakan lebih dari satu mesin dan melewati beberapa stasiun sebelum buah menjadi minyak. Stasiun pertama yaitu stasiun sterilizer atau stasiun perebusan, dimana buah didalam lori direbus kemudian dilanjutkan ke stasiun thresser untuk memisahkan antara buah dengan tandan, buah yang terpisah dari tandan diangkut dengan menggunakan fruit elevator menuju digester untuk dilakukan proses pelumatan pada buah dan pada saat buah masuk ke dalam Screw press buah diperas hingga minyak terpisah dengan daging buah dan biji. Screw press dan digester merupakan mesin yang sangat penting dalam menunjang kelancaran produksi pada sebuah pabrik kelapa sawit (PKS).

Pabrik minyak kelapa sawit begitu dominan di Riau, baik itu Pabrik Kelapa Sawit swasta maupun pabrik kelapa sawit badan usaha milik Negara (PTP-N). Selama kurun waktu 20 tahun terakhir kelapa sawit menjadi komoditas andalan ekspor dan komoditas yang diharapkan dapat meningkatkan pendapatan dan harkat petani serta para transmigrasi di Indonesia. Bagian kelapa sawit yang bernilai ekonomi tinggi adalah buahnya yang tersusun dalam sebuah tandan TBS (tandan buah segar). Buah sawit dibagian sabut (daging buah atau mesocarp) menghasilkan minyak sawit kasar (Crude Palm Oil) sebanyak 20-24\%. sementara itu, bagian inti sawit menghasilkan minyak inti sawit (Palm Kernel Oil atau PKO) 3$4 \%$. Prospek pasaran dunia untuk minyak sawit dan produk-produknya cukup bagus. karena itu, perkebunan kelapa sawit sekarang telah diperluas secara besar-besaran dengan pola perkebunan besar, pola perkebunan inti, pola Perkebunan Inti Rakyat (PIR), atau pola Kredit Koprasi Primer untuk Anggota (KKPA). Dengan banyaknya didirikan pabrik kelapa sawit tersebut tentu akan membutuhkan sumber daya manusia yang memahami tentang boiler sebagai penggerak utama pabrik sawit.

Salah satu stasiun pengolahan yang mempunyai masalah, yaitu stasiun pengempa (screw press). Permasalahan muncul pada saat kemampuan tekan dari screw press menurun yang terlihat pada hasil pressan buah sawit yang tidak kering sempurna. Setelah dilakukan observasi ke station pengolahan tersebut, ternyata gejala kerusakan terjadi pada komponen screw press yang mengakibatkan proses kerja terganggu. Kerusakan komponen yang terjadi adalah semakin menipisnya dimensi (ketebalan) screw press. Kerusakan diduga akibat beban tekan, oleh karena itu penulis melakukan penelitian terhadap komponen yang telah mengalami kerusakan tersebut untuk mencari karakteristik dari sifat mekanik matrial screw press yang mengalami kerusakan tersebut.

Kerusakan yang terjadi pada screw press ini sangat mempengaruhi kinerja dari pabrik kelapa sawit itu sendiri, dikarenakan stasiun screw press merupakan proses penting yakni memeras daging buah kelapa sawit untuk memisahkan daging buah dan biji guna mendapatkan minyak kelapa sawit. Bila terjadi kerusakan pada komponen screw press ini maka hasil dari pempressan tidak akan mendapatkan minyak secara maksimal.

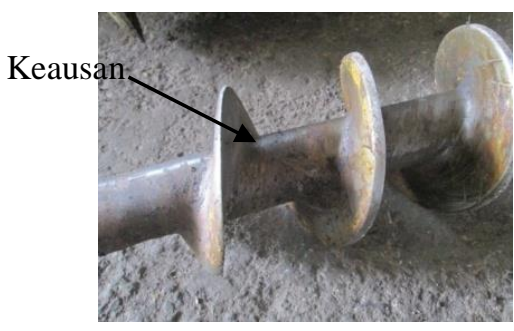

Gambar 1. Keausan pada screw press

Pada Gambar 1 terlihat kondisi screw press sudah mengalami keausan akibat pemakaian. Hal ini berakibat dengan turunnya kualitas dari hasil pressan buah kelapa sawit itu sendiri.

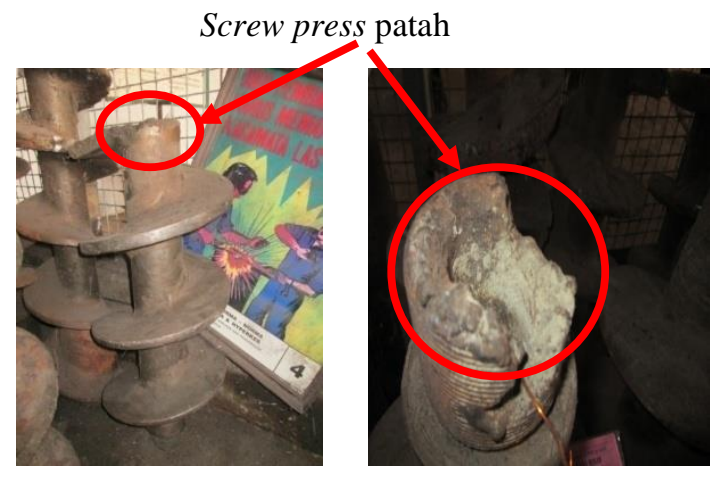

Gambar 2. Screw Press Patah

Pada Gambar 2 terlihat salah satu kerusakan yang terjadi pada screw press itu yang diakibatkan dari pemakaian screw press itu sendiri. Hal ini juga mempengaruhi proses pengepressan pada mesin press yang juga akan mempengaruhi kualitas minyak yang didapat dari proses pengepressan. 
Apabila kendala yang ada tidak tangani dengan baik maka akan berdampak terhadap timbulnya kerusakan pada material screw press.

Penelitian yang dilakukan ini bertujuan untuk :

1. Mengetahui karakteristik material screw press melalui beberapa pengujian antara lain uji tarik, kekerasan, struktur mikro dan komposisi material.

2. Menganalisis gaya-gaya dan tegangan pada screw press.

\subsection{Screw press}

Screw press adalah salah satu peralatan yang terdapat pada pabrik kelapa sawit. Dimana screw press ini terdapat pada mesin pengepress (Screw press). Fungsi dari pada screw press untuk memindahkan sekaligus mengepres buah sawit sehingga ampas terpisah dari cairan baik itu berupa air maupun minyak. Screw press terdiri atas dua unit, yang mana masing-masing unit memiliki ulir yang berlawanan dan arah putar yang berlawanan. Jarak ulir yang satu dengan yang lainnya tidak sama, dimana jarak ulir yang satu dengan yang lain semakin mengecil.

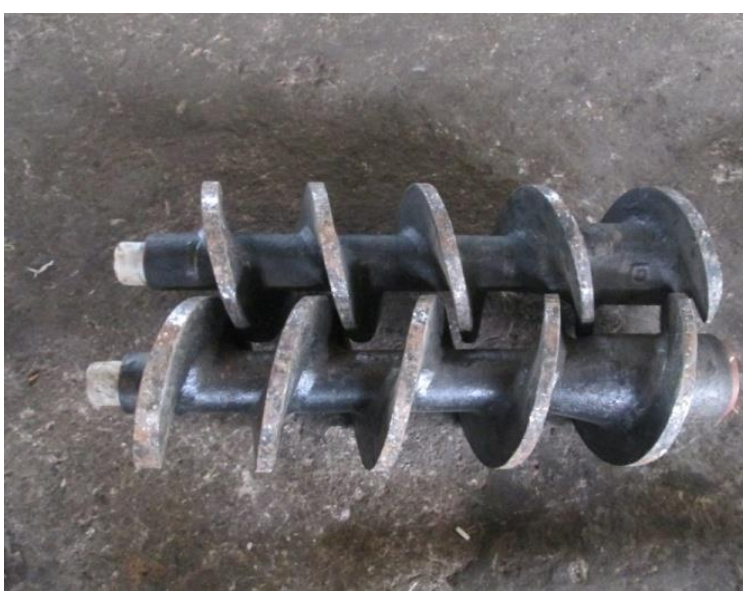

Gambar 3. Screw Press

Screw press yang digunakan terbuat dari baja material cor, yaitu baja paduan seperti terlihat pada Gambar 3 baja merupakan paduan yang terdiri atas besi, karbon dan unsur lainnya. Karbon merupakan salah satu unsur terpenting karena dapat meningkatkan kekerasan dan kekuatan baja. Kandungan karbon didalam baja sekitar 0,1-0,7\%, sedangkan unsur lain dibatasi persentasenya. Unsur paduan yang bercampur didalam lapisan baja untuk membuat baja bereaksi terhadap pengerjaan panas atau menghasilkan sifat-sifat khusus. Baja merupakan logam yang paling banyak digunakan keteknikan seperti pembentukan pelat, lembaran, pipa, batang, profil dan lain sebagainya. Unsur karbon adalah unsur campuran yang sangat penting dalam pembentukan baja, jumlah persentase dan bentuknya membawa pengaruh yang amat besar terhadap sifatnya. Tujuan penambahan material unsur campuran lain kedalam baja adalah untuk mengubah pengaruh unsur karbon. Apabila dibandingkan dengan kandungan karbonnya maka dibutuhkan sejumlah besar unsur campuran lain untuk menghasilkan sifat yang dikehendaki pada baja. Unsur-unsur campuran itu yaitu silikon (Si), mangan (Mn), chrom $(\mathrm{Cr})$, molibden, dan nikel $(\mathrm{N})$.

\subsection{Pengertian Aus}

Keausan adalah sebuah fenomena yang terjadi dalam bidang engineering. Keausan didefinisikan oleh ASTM (American Society for Testing and Material) sebagai kerusakan permukaan benda yang secara umum berhubungan dengan peningkatan hilangnya material yang disebabkan oleh pergerakan relatif benda dan sebuah subtansi kontak. Mekanisme keausan dibagi 2 kelompok yaitu keausan karena perilaku mekanis dan keausan karena perilaku kimiawi. Keausan karena perilaku mekanis dibagi menjadi 4 kelompok, antara lain :

1. Adhesive wear

Terjadi bila kontak permukaan dari dua material atau lebih mengakibatkan adanya perlekatan satu sama lainnya (adhesive) serta deformasi plastis dan pada akhirnya terjadi pelepasan/pengoyakan salah satu material seperti terlihat pada Gambar 4 dan 5.

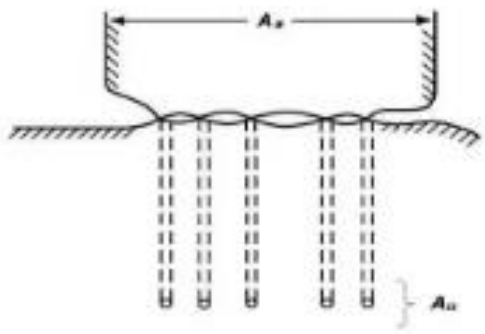

Gambar 4. Ilustrasi Keausan Adhesive

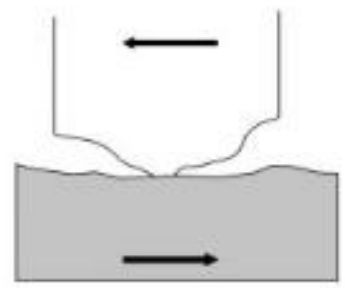

Gambar 5. Keausan Metoda Adhesive (Anonim, 2012)

Faktor yang menyebabkan adhesive wear: 
1. Kecenderungan dari material yang berbeda untuk membentuk larutan padat atau senyawa intermetalik.

2. Kebersihan permukaan.

Jumlah wear debris akibat terjadinya aus melalui mekanisme adhesive ini dapat dikurangi dengan cara, antara lain :

1. Menggunakan material keras.

2. Material dengan jenis yang berbeda, misal berbeda struktur kristalnya.

\section{Abrasive wear}

Terjadi bila suatu partikel keras (asperity) dari material tertentu meluncur pada permukaan material lain yang lebih lunak sehingga terjadi penetrasi atau pemotongan material yang lebih lunak, sebagai contoh partikel pasir silica akan menghasilkan keausan yang lebih tinggi ketika diikat pada suatu permukaan seperti pada kertas amplas, dibandingkan bila pertikel tersebut berada di dalam sistem slury.

Faktor yang berperan dalam kaitannya dengan ketahanan material terhadap abrasive wear antara lain:
a. Material hardness
b. Kondisi struktur mikro
c. Ukuran abrasif
d. Bentuk

\section{Erosive wear}

Keausan erosive dapat digambarkan sebagai gerakan meluncur yang sangat pendek dan dijalankan dalam interval waktu yang singkat, keausan erosive disebabkan oleh dampak dan partikel padat atau cair terhadap permukaan objek, partikel-partikel berdampak secara bertahap menghapus materi dan permukaan melalui deformasi berulang dan tindakan memotong, ini adalah mekanisme luas ditemui di industri, sebuah contoh umum adalah keausan erosive yang terkait dengan gerakan melalui perpipaan dan pemompaan peralatan.

Tingkat keausan erosive tergantung pada sejurnlah faktor karakteristik material dan partikel, seperti bentuk, kekerasan, kecepatan dan sudut, dampak pelampiasan adalah faktor utama bersama dengan sifat permukaan yang terkikis.

\section{Fatique Wear (Keausan Lelah)}

Keausan ini terjadi akibat interaksi permukaan material, dimana permukaan yang mengalami beban berulang akan mengarah pada pembentukan retakan-retakan mikro. Retakanretakan mikro tersebut pada akhirnya menyatu dan menghasilkan pengelupasan material. Tingkat keausan sangat bergantung pada tingkat pembebanan, Gambar 6 menunjukkan proses terjadinya keausan lelah.
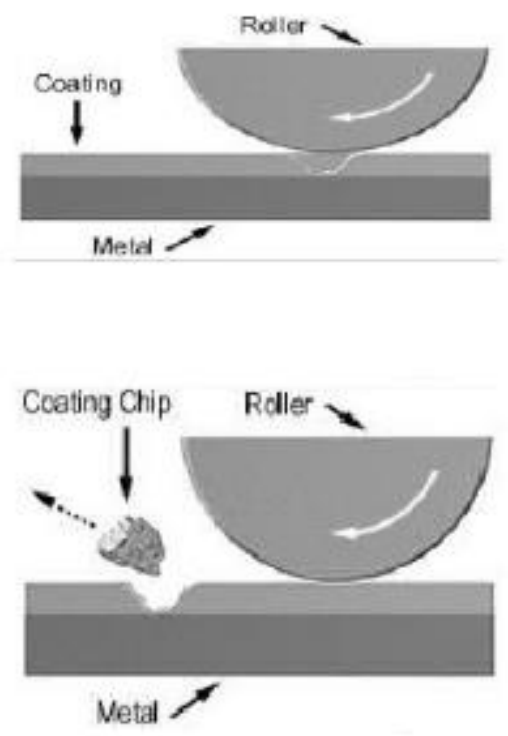

Gambar 6. Mekanisme Keausan Lelah (Anonim, 2012)

Sedangkan fenomena keausan yang kedua adalah keausan karena prilaku kimiawi, keausan karena prilaku kimiawi ini juga dibedakan menjadi 4 bagian yaitu:

a. Solution wear

b. Difusive wear

c. Keausan Oksidasi/Korosif ( Corrosive Wear)

Pada prinsipnya mekanisme ini dimulai dengan adanya perubahan kimiawi material di bagian permukaan oleh faktor lingkungan. Kontak dengan lingkungan ini akan menghasilkan pembentukan lapisan pada permukaan dengan sifat yang berbeda dengan material induk. Sebagai konsekuensinya, material pada lapisan permukaan akan mengalami keausan yang berbeda hal ini selanjutnya mengarah kepada perpatahan interface antara lapisan permukaan dan material induk dan akhirnya seluruh lapisan perrnukaan itu akan tercabut seperti terlihat pada Gambar 7.
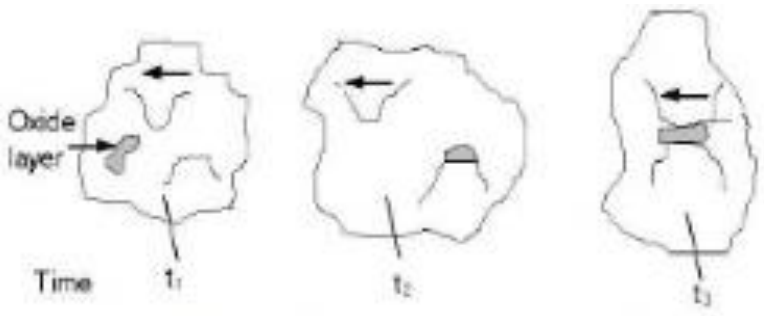

Gambar 7. Mekanisme Keausan Oksidasi (Anonim, 2012)

4. Keausan Erosi 
Erosi adalah peristiwa pengikisan padatan yang dipengaruhi oleh alarn. Proses erosi disebabkan oleh gas dan cairan yang membawa partikel padatan yang membentuk permukaan material. Jika sudut benturannya kecil, keausan yang dihasilkan analog dengan abrasive. Narnun, jika sudut benturannya membentuk sudut gaya normal $\left(90^{\circ}\right)$, maka keausan yang terjadi akan rnengakibatkan brittle frzilure pada permukaannya, skematis pengujiannya seperti pada Gambar 8.

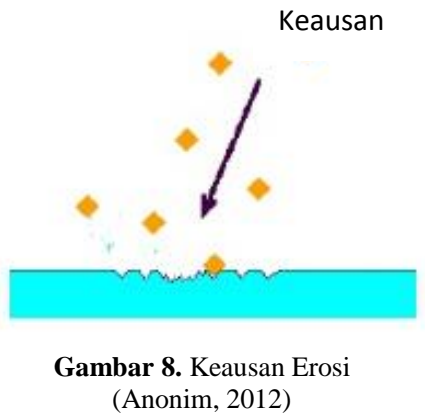

\section{Keausan pada screw press}

Screw press adalah salah satu komponen utama mesin pengekstraksi minyak kelapa sawit mentah (Crude Palm Oil) yang sangat rentan dengan keausan, masa pakai screw press di pabrik kelapa sawit PTPN V Kebun Sei Intan (700-800 jam) sering tidak sesuai dengan rekomendasi pabrik pembuatannya (1000 jam). Keausan yang terjadi ini perlu diminimalkan, karena mengganggu kinerja mesin screw press dan kerugian minyak sawit. Pemeliharaan korektif perlu diterapkan pada screw press untuk memberi perbaikan. Pemeliharaan korektif sementara yang dikerjakan karyawan pabrik adalah dengan mengelas kembali (rebuild) permukaan yang aus tersebut. Analisis awal dilakukan dengan menghitung respons yang bekerja pada screw press akibat tekanan konus. Dari survei didapat bahwa keausan terbesar terletak pada bagian ujung screw press yang mendapat tekanan langsung dari konus. Pada bagian ujung screw press dimodifikasi dengan menambahkan pelat pelapis yang telah mengalami pengerasan permukaan sehingga keausan akan terjadi pada pelat dan lebih mudah penggatiannya, proses rebuild screw press seperti terlihat pada Gambar 9.
Gambar 9. Screw Press Baru

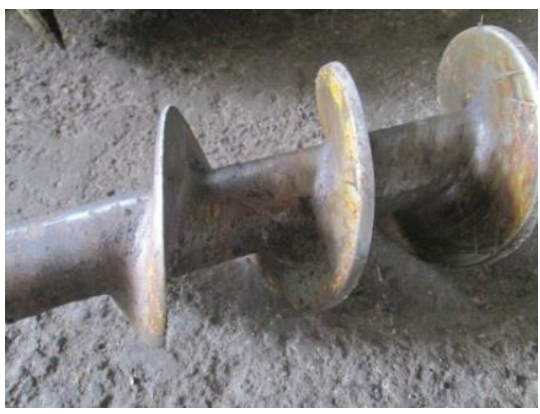

Gambar 10. Screw Press Mengalami Aus

\section{Logam}

\section{Sifat umum logam}

Logam yang banyak ditemukan dalam kehidupan sehari-hari, secara umum mempunyai sifat-sifat dapat mengkilat, dapat menghantar kalor dan listrik, berwarna putih seperti perak (kecuali tembaga berwarna kemerah-merahan dan emas berwarna kuning). Logam-logam tersebut mempunyai kekerasan yang berbeda-beda mulai dari lunak sekali (natrium dan kalium) sampai keras sekali (chrom), sementara raksa berbentuk cair.

Menurut massa jenisnya logam digolongkan atas logam berat (yang massa jenisnya $>5$ ), dan logam ringan (yang massa jenisnya $<5$ ).

Ditinjau dari sifat kimianya logam mempunyai oksida-oksida pembentuk basa dan berdasarkan sifat logam terhadap oksida ini logam tersebut dapat digolongkan menjadi:

1. Logam Mulia, yaitu logam yang tidak dapat mengalami oksida, misalnya; $\mathrm{Au}, \mathrm{Pt}, \mathrm{Ag}$ dan $\mathrm{Hg}$.

2. Logam setengah mulia ; yaitu logam yang agak sulit teroksidasi, misalnya $\mathrm{Cu}$.

3. Logam tidak mulia, yaitu logam-logam yang dalam keadaan biasa dan pada perubahan temperatur mudah teroksidasi misalnya $\mathrm{K}, \mathrm{Na}$, $\mathrm{Mg}, \mathrm{Ca}, \mathrm{Al}, \mathrm{Zn}, \mathrm{Fe}, \mathrm{Sn}, \mathrm{Pb}$ dan lain-lain.

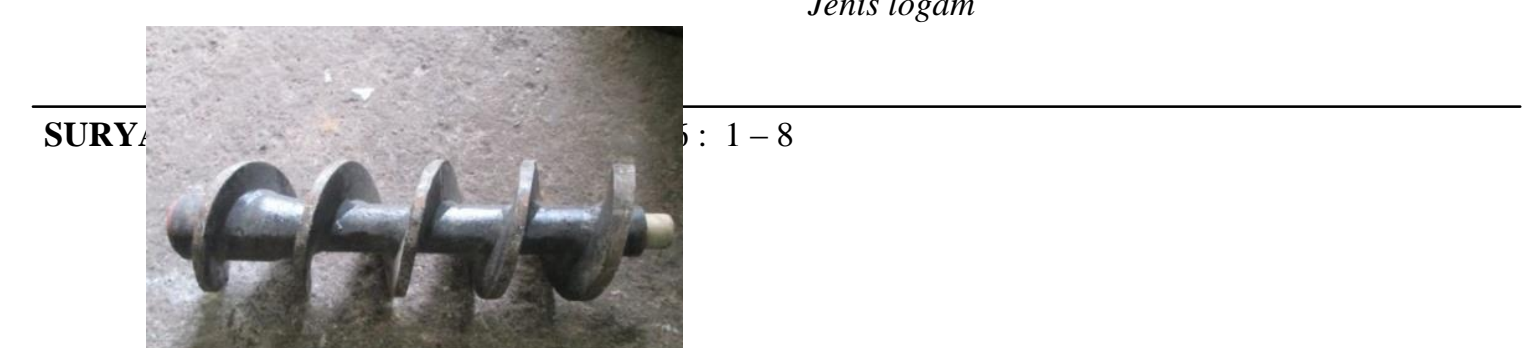


a. Logam Ferro (Logam besi)

Logam ferro adalah adalah logam besi $(\mathrm{Fe})$. Besi merupakan logam yang penting dalam bidang teknik, tetapi besi murni terlalu lunak dan rapuh sebagai bahan kerja, bahan konstruksi dan lainlain. Oleh karena itu besi selalu bercampur dengan unsur lain, terutama zat arang/karbon (C). Sebutan besi dapat berarti:

1. Besi murni dengan simbol kimia Fe yang hanya dapat diperoleh dengan jalan reaksi kimia.

2. Besi teknik adalah yang sudah atau selalu bercampur dengan unsur lain.

Besi teknik terbagi atas tiga macam :

1. Besi mentah atau besi kasar yang kadar karbonnya lebih besar dari 3,7\%.

2. Besi tuang yang kadar karbonnya antara 2,3 sampai 3,6\% dan tidak dapat ditempa. Pada besi tuang, karbon tidak bersenyawa secara kimia dengan besi melainkan sebagai karbon yang lepas yang memberikan warna abu-abu kehitaman, pada besi tuang putih karbon mampu bersenyawa dengan besi.

3. Baja atau besi tempa yaitu kadar karbonnya kurang dari 1,7\% dan dapat ditempa.

Logam ferro juga disebut besi karbon atau baja karbon. Bahan dasarnya adalah unsur besi $(\mathrm{Fe})$ dan karbon (C), tetapi sebenarnya juga mengandung unsur lain seperti: silisium, mangan, fosfor, belerang dan sebagainya yang kadarnya relatif rendah. Unsur-unsur dalam campuran itulah yang mempengaruhi sifat-sifat besi atau baja pada umumnya, tetapi unsur zat arang (karbon) yang paling besar pengaruhnya terhadap besi atau baja terutama kekerasannya.

\section{b. Logam Non Ferro}

Logam non ferro atau logam bukan besi adalah logam yang tidak mengandung unsur besi (Fe). Logam non ferro murni kebanyakan tidak digunakan begitu saja tanpa dipadukan dengan logam lain, karena biasanya sifat-sifatnya belum memenuhi syarat yang diinginkan. Kecuali logam non ferro murni, platina, emas dan perak tidak dipadukan karena sudah memiliki sifat yang baik, misalnya ketahanan kimia dan daya hantar listrik yang baik serta cukup kuat, sehingga dapat digunakan dalam keadaan murni. Karena harganya mahal, ketiga jenis logam ini hanya digunakan untuk keperluan khusus. Misalnya dalam teknik proses dan laboratorium di samping keperluan tertentu seperti perhiasan dan sejenisnya.

Logam non fero juga digunakan untuk campuran besi atau baja dengan tujuan memperbaiki sifat-sifat baja. Dari jenis logam non ferro berat yang sering digunakan untuk paduan baja antara lain, nekel, kromium, molebdenum, wllfram dan sebagainya. Sedangkan dari logam non ferro ringan antara lain: magnesium, titanium, kalsium dan sebagainya.

\section{Sifat Tarik}

Uji tarik merupakan salah satu pengujian untuk mengetahui sifat-sifat suatu bahan. Dengan menarik suatu bahan kita akan segera mengetahui bagaimana bahan tersebut bereaksi terhadap tenaga tarikan dan mengetahui sejauh mana material itu bertambah panjang

Bila terus ditarik (dalam hal ini suatu logam) sampai putus akan didapatkan profil tarikan yang lengkap berupa kurva seperti digambarkan pada Gambar.1.11. Kurva ini menunjukkan hubungan antara gaya tarikan dengan perubahan panjang. Profil ini sangat diperlukan dalam desain yang memakai bahan tersebut.

\section{Hukum Hooke}

Hampir semua logam, pada tahap sangat awal dari uji tarik, hubungan antara beban atau gaya yang diberikan berbanding lurus dengan perubahan panjang bahan tersebut. Ini disebut daerah linier atau linear zone. Di daerah ini, kurva pertambahan panjang vs beban mengikuti aturan Hooke yaitu rasio tegangan (stress) dan regangan (strain) adalah konstan.

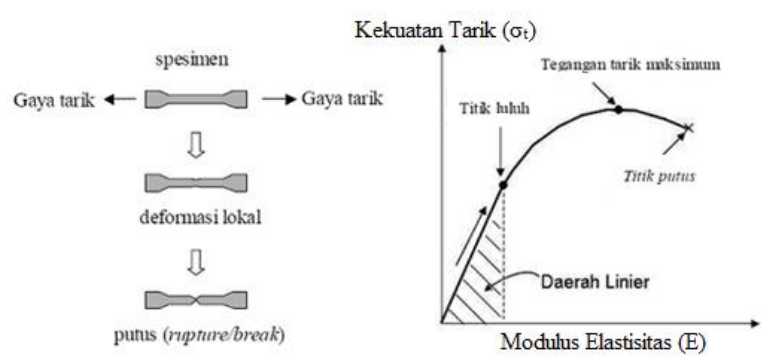

Gambar 11. Kurva Uji Tarik

\section{Modulus elastisitas}

Modulus elastisitas (E) merupakan pengukuran kemampuan material untuk menahan perubahan bentuk atau lentur yang terjadi sampai dengan batas elastisnya. Semakin besar bebannya, semakin tinggi tegangan yang timbul dan semakin besar perubahan bentuk yang terjadi sampai batas elastis.

Untuk menghitung modulus elastisitas dapat menggunakan persamaan 1.1 .

$$
\frac{\sigma_{2}-\sigma_{1}}{\mathrm{e}_{2}-\mathrm{e}_{1}} \ldots \ldots \ldots \ldots \ldots(1)
$$

Untuk menghitung kekuatan tarik dapat menggunakan persamaan 2 . 


$$
\sigma_{1}=\frac{F}{A}
$$

Keterangan:

$\mathrm{F}=$ gaya tarik $(\mathrm{kN})$

$\mathrm{A}=$ luas penampang spesimen uji (mm)

Untuk menghitung pertambahan panjang hasil uji tarik dapat menggunakan persamaan 3 .

$$
\Delta \mathrm{L}_{\mathrm{i}}=\frac{\mathrm{A}}{\mathrm{B}} \mathrm{x} \mathrm{C}
$$

Keterangan:

$\Delta \mathrm{L}_{\mathrm{i}} \quad=$ pertambahan panjang spesimen uji

$$
\text { (mm) }
$$

A $\quad=$ mm Grafik $(\mathrm{mm})$

$\mathrm{B}=$ titik maksimum pertambahan panjang (mm)

$\mathrm{C}=\mathrm{L}_{1}-\mathrm{L}_{0}(\mathrm{~mm})$

Untuk menghitung tegangan yang terjadi dapat digunakan persamaan 4 .

$$
\sigma_{1}=\frac{F_{i}}{A_{0}}
$$

Keterangan:

$\sigma_{1} \quad=$ tegangan yang terjadi $\left(\mathrm{kN} / \mathrm{mm}^{2}\right)$

$\mathrm{F}_{\mathrm{i}} \quad$ = gaya $(\mathrm{kN})$

$\mathrm{A}_{0} \quad=$ luas penampang $(\mathrm{mm})$

Untuk menghitung tegangan sebenarnya $\left(\sigma_{\mathrm{T}}\right)$ digunakan persamaan 5 .

$$
\sigma_{T i}=\sigma_{1}\left(1+e_{1}\right)
$$

Keterangan:

$$
\begin{array}{ll}
\sigma_{\mathrm{Ti}} & =\text { tegangan sebenarnya }\left(\mathrm{kN} / \mathrm{mm}^{2}\right) \\
\sigma_{1} & =\text { tegangan }\left(\mathrm{kN} / \mathrm{mm}^{2}\right) \\
\mathrm{e}_{1} & =\text { elastisitas }(\%)
\end{array}
$$

untuk menghitung regangan sebenarnya $\left(\Sigma_{\mathrm{T}}\right)$ digunakan persamaan 6 .

$$
\Sigma_{\mathrm{Ti}}=\ln (1+\mathrm{e})
$$

Keterangan:

$$
\begin{array}{ll}
\Sigma_{\mathrm{Ti}} & =\text { regangan sebenarnya } \\
\mathrm{e} & =\text { elastisitas }(\%)
\end{array}
$$

Untuk menghitung keuletan dapat ditentukan dengan persamaan 7 .

$$
\% \mathrm{e}=\frac{\mathrm{L}_{1}-\mathrm{L}_{0}}{\mathrm{~L}_{0}} \times 100 \%
$$

\section{Dimana :}

$$
\begin{array}{ll}
\mathrm{L}_{0} & =\text { panjang awal }(\mathrm{mm}) \\
\mathrm{L}_{1} & =\text { panjang akhir }(\mathrm{mm}) \\
\% \mathrm{e} & =\operatorname{keuletan}(\%)
\end{array}
$$

\section{Methodologi}

\subsection{Sfesifikasi}

Dimana mesin screw press yang digunakan pada penelitian ini dapat dilihat pada tabel berikut :

Tabel 1. Spesifikasi Mesin Screw press

\begin{tabular}{cc}
\hline Kapasitas & $10-14$ Ton/Jam \\
\hline Panjang Mesin & $4575 \mathrm{~mm}$ \\
\hline Lebar Mesin & $1520 \mathrm{~mm}$ \\
\hline Tinggi Mesin & $1025 \mathrm{~mm}$ \\
\hline Type Oli & ISO VG 450 \\
\hline Kapasitas Oli & $60 \mathrm{Ltr}$ \\
\hline Gearbox & Helical Geared \\
\hline Revolusi & $10-13 \mathrm{rpm}$ \\
\hline Daya Listrik & $22 \mathrm{~kW} / 30 \mathrm{Pk}$ \\
\hline
\end{tabular}

\subsection{Peralatan dan Material}

Peralatan yang digunakan dalam penelitian ini adalah :

1. Peralatan pengukuran

Jangka sorong untuk mengukur dimensi awal material sebelum dan sesudah pengujian uji tarik.

2. Peralatan pengujian

Alat uji tarik yang digunakan adalah Universal Test Machine (UTM) seperti pada gambar 12 .

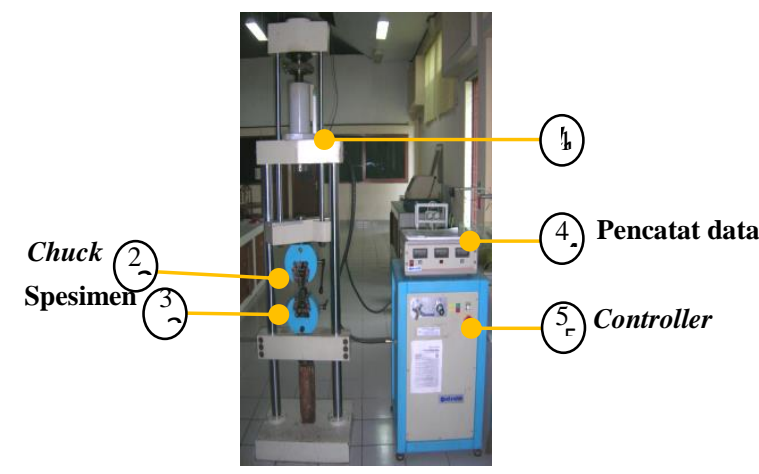

Gambar 12. Universal Test Machine (UTM)

3. Spesimen

Spesimen yang digunakan untuk uji tarik berdasarkan standar American Society for Testing and Material (ASTM). Sketsa geometri standar yang diperbolehkan dapat diperlihatkan pada Gambar 13.
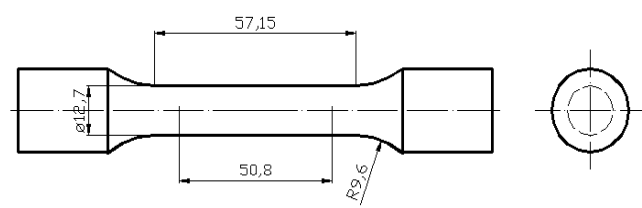

Gambar 13. Dimensi Spesimen Uji Tarik (ASTM E8 M) 


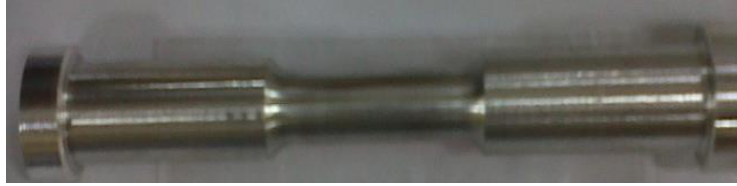

Gambar 14. Bentuk Spesimen Benda Uji

\section{Hasil dan Pembahasan}

\subsection{Perubahan Berat Akhir}

Fenomena perpindahan panas dari permukaan silinder ke permukaan biji kopi hijau terjadi pada saat proses penyangraian berlangsung. Panas yang dihasilkan pada saat penyangraian mengakibatkan terjadinya perubahan massa jenis dari biji kopi. Proses perubahan massa jenis terjadi ketika kandungan air di dalam biji kopi telah sampai pada kondisi jenuh dan menyebabkan kandungan air di dalam biji kopi secara bertahap akan mengalami proses penguapan. Perubahan ini terlihat nyata pada hasil penyangraian di Tabel 4.

Tabel 4.

Berat Akhir Hasil Penyangraian

\begin{tabular}{ccccccc}
\hline Data & $\begin{array}{c}\mathrm{T} \\
(\mathrm{C})\end{array}$ & $\begin{array}{c}\mathrm{W} \\
(\mathrm{s})\end{array}$ & $\begin{array}{c}\mathrm{Rh} \\
(\%)\end{array}$ & $\begin{array}{c}\mathrm{n} \\
(\mathrm{rpm} \\
)\end{array}$ & $\begin{array}{c}\text { Berat } \\
\text { Akhir } \\
(\text { Gram })\end{array}$ & $\begin{array}{c}\text { Berat } \\
\text { Hilang } \\
(\text { Gram })\end{array}$ \\
\hline 1 & 170 & 12 & 8 & 40 & 83 & 17 \\
\hline 2 & 170 & 14 & 6 & 50 & 82 & 18 \\
\hline 3 & 180 & 12 & 6 & 60 & 82 & 18 \\
\hline
\end{tabular}

Tabel 4 memperlihatkan perubahan berat biji kopi sangrai yang dihasilkan setelah dilakukan proses penyangraian. Biji kopi hijau disiapkan seberat 100 gram untuk masing-masing percobaan. Percobaan pertama dilakukan dengan temperatur $170 \mathrm{C}$, lama penyangraian 12 menit, kadar air $8 \%$ dan putaran silinder $40 \mathrm{rpm}$ mengakibatkan terjadinya penyusutan berat sebesar 17 gram sehingga berat akhir dari biji kopi sangrai yang dihasilkan adalah 83 gram. Percobaan kedua dilakukan dengan temperatur $170 \mathrm{C}$, lama penyangraian 14 menit, kadar air $6 \%$ dan putaran silinder $50 \mathrm{rpm}$ mengakibatkan terjadinya penyusutan berat sebesar 18 gram sehingga berat akhir dari biji kopi sangrai yang dihasilkan adalah 82 gram. Percobaan ketiga dilakukan dengan temperatur $180 \mathrm{C}$, lama penyangraian 12 menit, kadar air $6 \%$ dan putaran silinder $60 \mathrm{rpm}$ mengakibatkan terjadinya penyusutan berat sebesar 18 gram sehingga berat akhir dari biji kopi sangrai yang dihasilkan adalah 82 gram. keadaan ini menunjukkan terjadinya suatu reaksi pelepasan uap air. Temperatur, waktu, kadar air dan putaran berpengaruh terhadap laju pelepasan uap air pada biji kopi hijau. Dari data diatas dapat disimpulkan, bahwa pemakaian blower pada saat penyangraian tidak begitu berpengaruh terhadap perubahan berat yang dihasilkan pada kopi sangrai.

\subsection{Perubahan Tingkat Keasaman ( $p H)$}

Temperatur dan waktu proses penyangraian mempengaruhi tingkat keasaman $(\mathrm{pH})$ dari biji kopi sangrai. Tabel 5 memperlihatkan tingkat keasaman dari biji kopi setelah dilakukan proses penyangraian. Percobaan pertama dilakukan dengan temperatur $170 \mathrm{C}$, lama penyangraian 12 menit, kadar air $8 \%$ dan putaran silinder $40 \mathrm{rpm}$ menghasilkan nilai $\mathrm{pH}$ sebesar 6,08 menggunakan blower dan 6,13 tidak menggunakan blower. Percobaan kedua dilakukan dengan temperatur 170 C, lama penyangraian 14 menit, kadar air $6 \%$ dan putaran silinder $50 \mathrm{rpm}$ menghasilkan nilai $\mathrm{pH}$ sebesar 6,21 menggunakan blower dan 6,27 tidak menggunakan blower. Percobaan ketiga dilakukan dengan temperatur $180 \mathrm{C}$, lama penyangraian 12 menit, kadar air $6 \%$ dan putaran silinder $60 \mathrm{rpm}$ menghasilkan nilai $\mathrm{pH}$ sebesar 6,28 menggunakan blower dan 6,54 tidak menggunakan blower. Data ini menunjukkan perubahan tingkat keasaman cendrung mendekati nilai $\mathrm{pH}$ 7. Penggunaan blower pada saat penyangraian akan menghasilkan tingkat keasaman yang sedikit rendah jika dibandingkan dengan tidak menggunakan blower.

Tabel 5. Tingkat Keasaman (PH) dari Kopi Sangrai

\begin{tabular}{cccccccc}
\hline & & & & & & \multicolumn{2}{c}{ Keasaman $(\mathrm{PH})$} \\
\cline { 6 - 7 } Data & $\begin{array}{c}\mathrm{T} \\
(\mathrm{C})\end{array}$ & $\begin{array}{c}\mathrm{W} \\
(\mathrm{s})\end{array}$ & $\begin{array}{c}\mathrm{Rh} \\
(\%)\end{array}$ & $\begin{array}{c}\mathrm{n} \\
(\mathrm{rpm})\end{array}$ & $\begin{array}{c}\text { Tanpa } \\
\text { Blower }\end{array}$ \\
\hline 1 & 170 & 12 & 8 & 40 & 6,08 & 6,13 \\
\hline 2 & 170 & 14 & 6 & 50 & 6,21 & 6,27 \\
\hline 3 & 180 & 12 & 6 & 60 & 6,28 & 6,54 \\
\hline
\end{tabular}

\subsection{Perubahan Kecerahan Warna}

Tabel 6 memperlihatkan tingkat kecerahan warna yang dihasilkan pada proses penyangraian biji kopi. Proses penyangraian menghasilkan tingkat kecerahan yang bervariasi, mulai dari kecoklatan sampai kehitaman. Hal ini dipengaruhi oleh temperatur, waktu, kadar air dan putaran silinder saat proses penyangraian. Temperatur yang semakin tinggi dan lamanya proses penyangraian menyebabkan biji kopi semakin menghitam. Hal ini dapat dilihat pada data satu dimana hasil penyangraian memiliki warna kecoklatan yang digolongkan pada penyangraian ringan (light roast). Sedangkan pada data dua, hasil penyangraian memiliki warna agak kehitaman yang digolongkan pada penyangraian sedang (medium roast). Sementara pada data tiga, hasil penyangraian memiliki warna hitam yang digolongkan pada penyangraian gelap (dark roast).

Tabel 6. Tingkat Kecerahan Warna 


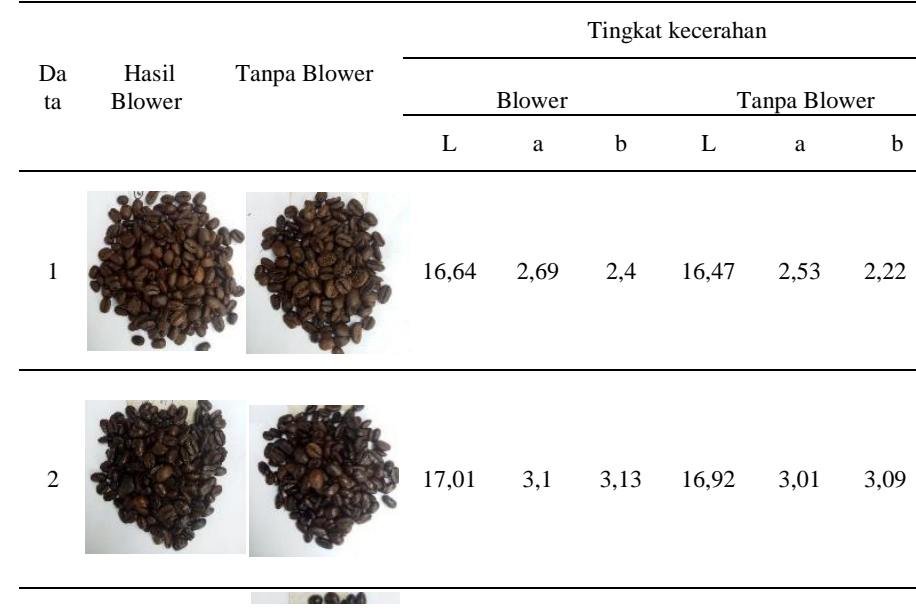
Penggunaan blower dan tanpa blower pada proses penyangraian menghasilkan tingkat kecerahan warna yang tidak begitu berbeda. Hasil pengukuran warna dari biji kopi sangrai didapat penurunan nilai L. Hal ini menandakan tingkat kecerahan warna semakin gelap, sedangkan nilai a dan b menunjukkan arah kepekatan dari hasil pengukuran. Sehingga dapat diartikan penggunaan blower pada mesin sangrai tidak mempengaruhi perubahan warna dari biji kopi sangrai yang dihasilkan

\subsection{Kadar CO2 pada Saat Penyangraian}

Proses penyangraian biji kopi mengakibatkan terjadinya penguapan kadar air dan pelepasan gas CO2 pada biji kopi hijau. Tabel 7 dan Tabel 8 menunjukkan pelepasan gas $\mathrm{CO} 2$ pada saat penyangraian biji kopi menggunakan blower maupun tanpa menggunakan blower. Temperatur penyangraian sangat berperan dalam proses pelepasan gas $\mathrm{CO} 2$. Hal ini dapat dilihat pada data tiga temperatur penyangraian $180 \mathrm{C}$, pelepasan gas $\mathrm{CO} 2$ tiap menit sangat signifikan jika dibandingkan dengan data satu dan data dua.

Pada data satu, penyangraian dengan menggunakan blower menghasilkan kadar CO2 sebesar 0,8\% dan tanpa menggunakan blower sebesar $0,9 \%$. Sedangkan data kedua penyangraian dengan menggunakan blower mengahasilkan kadar gas $\mathrm{CO} 2$ sebesar $0,9 \%$ dan tanpa menggunakan blower sebesar 1\%. Sementara data ketiga, penyangraian dengan menggunakan blower menghasilkan kadar $\mathrm{CO} 2$ sebesar 1,9\% dan tanpa menggunakan blower sebesar 2\%. Dari data di atas dapat disimpulkan, bahwa penggunaan blower pada saat penyangraian akan menghasikan kadar gas $\mathrm{CO} 2$ yang sedikit rendah jika dibandingkan dengan tidak menggunakan blower.

\section{Simpulan}

Hasil proses penyangraian kopi dipengaruhi oleh beberapa faktor diantaranya temperatur, waktu, kadar air dan putaran silinder. Hasil akhir dari perubahan berat, tingkat keasaman, kecerahan warna dan kadar $\mathrm{CO} 2$ tidak begitu dipengaruhi oleh pemakaian blower maupun tanpa menggunakan blower. Penggunaan blower pada mesin sangrai dapat menghilangkan aroma tidak sedap akibat keluarnya gas amoniak dari biji kopi yang sering disebut bau tengik. Selain itu, kualitas biji kopi sangrai yang memiliki aroma yang enak ditandai dengan kecerahan warna $(\mathrm{L})=17,01$ a $=3,1 \mathrm{~b}=3,13$ dan kandungan gas $\mathrm{CO} 2$ yang dihasilkan sebesar $0,9 \%$. Hasil ini terdapat pada temperatur $170 \mathrm{C}$, waktu penyangraian 14 menit, kadar air $6 \%$ dan putaran silider sangrai $50 \mathrm{rpm}$ dengan menggunakan blower sebagai hisapan asap.

Tabel 7.

Nilai CO2 Menggunakan Blower

\begin{tabular}{cccccccccccccccc}
\hline & \multicolumn{11}{c}{ Nilai CO2 Menggunakan Blower (\%) Waktu (Menit) } \\
\cline { 2 - 15 } & 1 & 2 & 3 & 4 & 5 & 6 & 7 & 8 & 9 & 10 & 11 & 12 & 13 & 14 \\
\hline 1 & 0 & 0 & 0,1 & 0,2 & 0,4 & 0,5 & 0,6 & 0,6 & 0,6 & 0,7 & 0,8 & 0,8 & & \\
\hline 2 & 0 & 0 & 0,3 & 0,4 & 0,5 & 0,5 & 0,6 & 0,6 & 0,6 & 0,6 & 0,7 & 0,8 & 0,9 & 0,9 \\
\hline 3 & 0 & 0,3 & 0,5 & 0,7 & 0,8 & 0,8 & 0,9 & 1,1 & 1,4 & 1,7 & 1,9 & 1,9 & & \\
\hline
\end{tabular}

Tabel 8.

Nilai CO2 Tanpa Blower

\begin{tabular}{ccccccccccccccc}
\hline & \multicolumn{11}{c}{ Nilai CO2 Tanpa Blower (\%) Waktu (Menit) } \\
\cline { 2 - 5 } & 1 & 2 & 4 & 5 & 6 & 7 & 8 & 9 & 10 & 11 & 12 & 13 & 14 \\
\hline 1 & 0 & 0 & 0,2 & 0,2 & 0,4 & 0,4 & 0,5 & 0,6 & 0,6 & 0,8 & 0,8 & 0,9 & & \\
\hline 2 & 0 & 0,1 & 0,3 & 0,4 & 0,5 & 0,5 & 0,6 & 0,6 & 0,7 & 0,7 & 0,8 & 0,9 & 0,9 & 1,0 \\
\hline
\end{tabular}




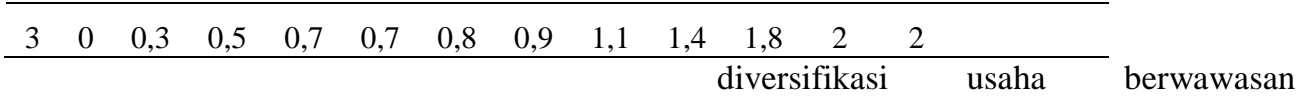
lingkungan dalam pengembangan

\section{Daftar Pustaka}

[1] Kumazawa, K., Masuda, H.: Investigation of the Change in the Flavor of a Coffee Drink during Heat Processing. J. Agric. Food Chem. 51, (2003) 2674-2678.

[2] Clague, R. Millard, M. \& Gibson, D. (2009). Beyond the Bean: Redefining Coffee Quality. pp. 1-18. Environment and Natural Resource Management and Agribusiness Practice Networks.

[3] http://www.aeki-aice.org

[4] Martin, M.J., Pablos, F., Gonzalez, A.G.: Discrimination between arabica and robusta green coffee varieties according to their chemical composition. Talanta. 46, (1998) 1259-1264.

[5] Baggenstoss, J.Poisson, L.Kaegi, R. Perren, R \&Escher, F (2008). Coffee Roasting and Aroma Formation: Application of Different Timetemperature Conditions. Journal of Agricultural and Food Chemistry 56 (14), 5836-5846.

[6] Franca, A. S., Mendonca, J. C. F., Oliveira, S. D.: Composition of green and roasted coffees of different cup qualities. LWT. 38, (2005) 709-715.

[7] Hernandez, J. A. Heyd, B.Irles, C.Valdovinos, B.\&Trystram, G. (2007). Analysis of the heat and mass transfer during coffee batch roasting. Journal of Food Engineering 78(4), 1141-1148.

[8] Yeretzian, C. Jordan, A. Badour, R. \& lsindinger, W. (2002). From the green bean to the cup of coffee: investigating coffee roasting by on-line monitoring of volatiles. European Food Research and Technology 214 (2), 92-104.

[9] Buffo, R. A. \& CardelliI-Freire, C. (2004). Coffee flavour: an overview. Flavour and Fragrance Journal 19 (2), 99-104.

[10] Mulato, sri. 2002. Simposium Kopi 2002 dengan tema mewujudkan perkopian nasional yang tangguh melalui industri kopi bubuk skala kecil untuk meningkatkan nilai tambah usaha tani kopi rakyat. Denpasar : 16 -17oktober 2002. Pusat penelitian dan kakao indonesia

[11] Geiger, R. Perren, R. Kuenzli, R. \& Escher, F. (2005). Carbon Dioxide Evolution and Moisture Evaporation During Roasting of Coffee Beans. Journal of Food Science 70(2), E124E130.

[12] Nkondjock A. 2009. Coffee consumption and the risk of cancer: an overview. Cancer Letters 277(2):121-5.

[13] Joko Nugroho W.K, Juliaty Lumbanbatu, Sri Rahayoe (2009) Pengaruh Suhu dan Lama Penyangraian Terhadap Sifat Fisik Mekanis Biji Kopi Robusta.

[14] Schwartzberg, H. G. (2000). Modelling bean heating during batch roasting of coffee beans. In Itextit\{Engineering and Food for the 21 Century, edited by J. Welti-Chanes, G. Barbosa-Canovas, JM Aguilera, CRC Press LLC, London, New York, Boca Raton.

[15] Belitz, H.-D. Grosch, W. \& Schieberle, P. (2009). Coffee, Tea, Cocoa. Vatican Springer Berlin Heidelberg.

[16] Hernández, J.A., B. Heyd, G. Trystram, 2008. On-line assessment of brightness and surface area kinetics during coffee roasting. Journal of Food Engineering, 87: 314-322.

[17] Rinaldi Munir. "Pengolahan Citra Digital dengan Pendetakan Algoritmik". InformatikaBandung, Bandung. 2004.

[18] Suyatma, 2009. Diagram Warna Hunter (Kajian Pustaka). Jurnal Penelitian Ilmiah Teknologi Pertanian, Institut Pertanian Bogor, Page 8-9. 